\title{
EDUCATION FOR BUSINESS AND MANAGEMENT
}

\begin{abstract}
$\mathrm{HE}$ debate on education for business and management which Lord Alport opened in the House of Lords on November 18, in which Lord Snow made a distinguished maiden speech as Parliamentary Secretary to the Ministry of Technology, greatly transcended any previous debate in Parliament this session, and was, moreover, free from the pettiness which has marred most of those in the House of Commons so far. Lord Snow did not attempt to claim all the credit for advances in management education for the Government, but, apart from his tributes to the work of Lord Franks, Lord Robbins, Lord Nelson of Stafford and Lord Normanbrook, for example, generously acknowledged the foundation laid by the previous Government and stressed the need for close co-operation between Government, industry and the academic world, without concern as to who received the credit. After mentioning the support which Lord Nelson had secured from industry for the two new business schools, Lord Snow stressed the imperative necessity for us to use with intelligence and imagination every scientific resource we had and he put management studies among the twelve or twenty most important tasks we had to tackle for survival within the next two or three years. Besides the two new institutions there were courses at various universities or colleges of advanced technology leading to a postgraduate degree, courses at regional colleges of technology leading to diploma in management studies, and finally a large amount of management education within firms themselves. Lord Snow declined to say that any one method was more important than the others: all would be needed. Probably less than 3 per cent of managers required no training, and apart from perhaps 20 or 30 per cent who would not be improved, the rest would be greatly improved by training. The next problem was to find the teachers, and here much more part-time help from industry was essential. Industry, too, had to make appropriate dispositions to utilize those who had been trained; finally, there was the vital problem of effective selection.
\end{abstract}

Most of these points had been put in questions by Lord Alport, but Lord Snow did not reply to his question about the need for increased research facilities. This aspect was specially emphasized by Lord Bowden later in the debate, who thought it was even more important that industry should co-operate in this field than that it should cooperate in teaching. Unless research workers from a business school could go into industry and investigate industrial problems on the shop floor the subject would never advance. Lord Bowden illustrated his point by referring to two investigations carried out from the Manchester College of Science and Technology within the past two or three years. The first, with the active support of the Ministry of Health and the collaboration of the hospitals concerned, was into a group of hospitals of similar size, appearance and scope and revealed remark- able differences in the skill with which hospitals could retain and train nursing staff and in the time taken for a patient to recover from similar conventional operations. Another survey, of the attitudes of workpeople to general problems of innovation and change, indicated variations between factories which greatly exceeded those within a factory, and the differences in attitude of mind were strongly correlated with the communications system within the factory.

Lord Bowden maintained that such problems of the pathology of a hospital or factory were much more easily handled by investigators with the impartial reputation that a business school or a university could ensure and he believed that in this way such institutions could make an important contribution in efficiency.

Earlier in the debate, the Bishop of Chichester, supported by Lord Kilmuir, had emphasized the personal aspects and particularly the importance of people, alike in research and in training for management: there was a moral aspect which could not be disregarded. Lord Plowden put his emphasis on co-operation between industry, the universities and the Government, while Lord Nelson of Stafford stressed the importance of making the most of existing experience, of securing an adequate supply of trained teachers, of effective coordination between the various types of courses, and of the Government ensuring that adequate grants were available for the students who came forward. Lord Chorley, who referred to the Beveridge Experimental School of Economics, thought the failure of the earlier schemes was worth studying and that the pioneer work of Lord Beveridge was not sufficiently appreciated. Lord Geddes of Epsom, commenting on the increasing need for managers to be scientifically minded, raised an important point about the use of scientists as administrators: it could be a serious situation if scientists could not easily enter the managerial class if they were competent. Lord Aberdare stressed the need for first-class and imaginative teachers in the business schools and supported Lord Bowden's remarks about constant interchange between the academic and the industrial world. Lord Shackleton, in concluding the dobate for the Government, was also studiously fair in acknowledging what had already been done under the previous Government, but was unable to offer at this stage any firm assurance about grants for students, and while he undertook that the Government would continue to co-operate he could say little on co-ordination, and the responsibility for management education, he said, would lie with the Secretary of State for Education and Science, and, for non-university courses in Scotland, with the Secrotary of State for Scotland. Although the Ministry of Technology, the Board of Trade, and the Ministry of Labour might also be concerned, management education should properly grow out of the educational system.

\section{SCIENTIFIC AND INDUSTRIAL RESEARCH IN NEW ZEALAND}

WHE annual report of the Department of Scientific
and Industrial Research, New Zealand, for the year
ended March 31,1964 (Pp. 87 . Wellington: Government
Printer, 1964 . $3 s$. , records a gross expenditure of
$£ 2,607,112$, or $£ 2,538,794$ net, of which about 42 per cent
is estimated to be on agricultural research and 27 per cent
on industrial research, including grants totalling $£ 200,577$
to incorporated research associations. Rather less than
10 per cent of the total expenditure is for scientific services, mainly for other Government Departments and for industry. The major items of expenditure were $£ 279,253$ on the Dominion Physical Laboratory, $£ 264,265$ on the Dominion Laboratory, $£ 165,908$ on the Geophysics Division, $£ 138,061$ on the Soil Bureau, $£ 132,616$ on the Geological Survey, $£ 122,414$ on the Grasslands Division, $£ 116,471$ on the Antarctic Division, $£ 111,524$ on the Plant Diseases Division, and $\mathfrak{1 9 4 , 4 5 8}$ on the Oceanographic Institute. The staff increased during the year from 1,229 